\title{
Development of Graves' Disease After SARS-CoV-2 mRNA Vaccination: A Case Report and Literature Review
}

\author{
David Tak Wai Lui, Ka Kui Lee, Chi Ho Lee, Alan Chun Hong Lee, Ivan Fan Ngai Hung and \\ Kathryn Choon Beng Tan*
}

Department of Medicine, The University of Hong Kong, Queen Mary Hospital, Hong Kong, Hong Kong SAR, China

OPEN ACCESS

Edited by:

Talha Bin Emran,

Begum Gulchemonara Trust

University, Bangladesh

Reviewed by:

Mohammad Injamul Hoq

University of Creative Technology

Chittagong, Bangladesh

Philippe Jean Caron,

Centre Hospitalier Universitaire de

Toulouse, France

*Correspondence:

Kathryn Choon Beng Tan kcbtan@hku.hk

Specialty section:

This article was submitted to Infectious Diseases - Surveillance,

Prevention and Treatment,

a section of the journal

Frontiers in Public Health

Received: 11 October 2021 Accepted: 02 November 2021

Published: 23 November 2021

Citation:

Lui DTW, Lee KK, Lee CH, Lee ACH,

Hung IFN and Tan KCB (2021)

Development of Graves' Disease After SARS-COV-2 mRNA Vaccination: A

Case Report and Literature Review.

Front. Public Health 9:778964.

doi: 10.3389/fpubh.2021.778964
Background: Mounting evidence has revealed the interrelationship between thyroid and severe acute respiratory syndrome coronavirus 2 (SARS-CoV-2) to explain the thyroid dysfunction and autoimmune thyroid disorders observed after coronavirus disease 2019 (COVID-19). There are limited reports of thyroid dysfunction after SARS-CoV-2 vaccination.

Methods: We report a case of a 40-year-old Chinese woman who developed Graves' disease after BNT162b2 mRNA vaccine. A search of PubMed and Embase databases from 1 September 2019 to 31 August 2021 was performed using the following keywords: "COVID," "vaccine," "thyroid," "thyroiditis," and "Graves."

Results: A 40-year-old Chinese woman who had 8-year history of hypothyroidism requiring thyroxine replacement. Her anti-thyroid peroxidase and anti-thyroglobulin antibodies were negative at diagnosis. She received her first and second doses of BNT162b2 mRNA vaccine on 6 April and 1 May 2021, respectively. She developed thyrotoxicosis and was diagnosed to have Graves' disease 5 weeks after the second dose of vaccine, with positive thyroid stimulating immunoglobulin level, diffuse goiter with hypervascularity on thyroid ultrasonography and diffusely increased thyroid uptake on technetium thyroid scan. Both anti-thyroid peroxidase and anti-thyroglobulin antibodies became positive. She was treated with carbimazole. Literature search revealed four cases of Graves' disease after SARS-CoV-2 vaccination, all after mRNA vaccines; and nine cases of subacute thyroiditis, after different types of SARS-CoV-2 vaccines.

Conclusion: Our case represents the fifth in the literature of Graves' disease after SARS-CoV-2 vaccination, with an unusual presentation on a longstanding history of hypothyroidism. Clinicians should remain vigilant about potential thyroid dysfunction after SARS-CoV-2 vaccination in the current pandemic.

Keywords: COVID-19, SARS-CoV-2, COVID-19 vaccines, Graves' disease, thyroiditis, autoimmunity 


\section{INTRODUCTION}

Hopefully vaccination against severe acute respiratory syndrome coronavirus 2 (SARS-CoV-2) will bring an end to the current intense fight against the coronavirus disease 2019 (COVID19) pandemic. Following reports of COVID-related thyroiditis and autoimmune thyroid disorders such as Graves' disease (1), there are concerns that SARS-CoV-2 vaccination may also be associated with thyroid dysfunction.

Indeed, there are several case reports of thyroiditis after SARS-CoV-2 vaccination. These events of thyroiditis occurred after mRNA vaccines $(2,3)$, inactivated vaccines (3-6) and adenovirus-vectored SARS-CoV-2 vaccines (7). In contrast, reports of Graves' disease occurring after SARS-CoV-2 vaccines are restricted to after mRNA vaccines $(8,9)$.

Here we report a 40-year-old Chinese woman who developed Graves' disease after SARS-CoV-2 mRNA vaccination, on a background of longstanding hypothyroidism stable on thyroxine replacement. We also take this opportunity to review the currently available reports of thyroid dysfunction after SARSCoV-2 vaccination.

\section{MATERIALS AND METHODS}

Written informed consent was obtained from the patient for publication of this case report and any accompanying images. We performed a literature search of PubMed and Embase databases regarding thyroid dysfunction after SARS-CoV-2 vaccination, from 1 September 2019 to 31 August 2021, using the following keywords: "COVID," "vaccine," "thyroid," "thyroiditis," and "Graves."

\section{RESULTS}

\section{Case Presentation}

A 32-year-old Chinese woman, with good past health and no family history of thyroid disorders, presented in September 2013 with cold intolerance and lethargy. Thyroid function test showed subclinical hypothyroidism: thyroid stimulating hormone (TSH) level was $5.30 \mathrm{mIU} / \mathrm{L}$ (reference range: 0.27-4.20) and free thyroxine (fT4) level was $13.9 \mathrm{pmol} / \mathrm{L}$ (reference range: 12.022.0), similar on repeat. Her anti-thyroid peroxidase (anti-TPO) and anti-thyroglobulin (anti-Tg) were negative (anti-TPO $<5.0$ $\mathrm{IU} / \mathrm{mL}$, reference range $<34.0$; anti-TPO $<10 \mathrm{IU} / \mathrm{mL}$, reference range $<115$ ). She was initially given an intermediate dose of thyroxine 50 microgram daily (i.e., 350 microgram weekly; her body weight was $50 \mathrm{~kg}$ ), and stabilized on a thyroxine dose of 50 microgram for 5 days per week and 100 microgram daily for 2 days per week, totally 450 microgram per week. Subsequent thyroid function remained normal with this dosage of thyroxine. Her symptoms also improved with thyroxine replacement. Her serial thyroid function test results are listed in Table 1. Routine follow-up in July 2020 showed normal TSH and fT4. She remained clinically euthyroid.

In the COVID-19 pandemic, now 40 years of age, she has not been infected with COVID-19. She received her first and second doses of BNT162b2 mRNA vaccine (Comirnaty) on 6 April and 1 May 2021, respectively. Subsequently, she presented with palpitation and was noted to have sinus tachycardia upon visit to private practitioner on 8 June 2021.

Blood tests revealed a picture of thyrotoxicosis: TSH $<0.02$ $\mathrm{mIU} / \mathrm{L}$ (reference range: $0.47-4.68$ ), fT4 $66.6 \mathrm{pmol} / \mathrm{L}$ (reference range: $10.0-28.2$ ) and fT3 $30.50 \mathrm{pmol} / \mathrm{L}$ (reference range: 4.268.10). Physical examination revealed a moderate diffuse goiter with thyroid bruit. She did not have signs of Graves' orbitopathy or dermopathy. Her thyroid stimulating immunoglobulin (TSI) level was $420 \%$ (reference range: $<140 \%$ baseline). Interestingly, both her anti-TPO and anti-Tg became positive (anti-TPO $239.2 \mathrm{kIU} / \mathrm{L}$, reference range: $<5.6$; anti-Tg $7.2 \mathrm{kIU} / \mathrm{L}$, reference range $<4.1)$. Thyroid ultrasonography revealed a heterogeneous background thyroid echogenicity with increase in vascularity, suggestive of diffuse thyroid disease (Figure 1). Her technetium thyroid scan showed findings typical of Graves' disease: diffuse

TABLE 1 | Serial thyroid function tests and anti-thyroid antibody titers in our reported case.

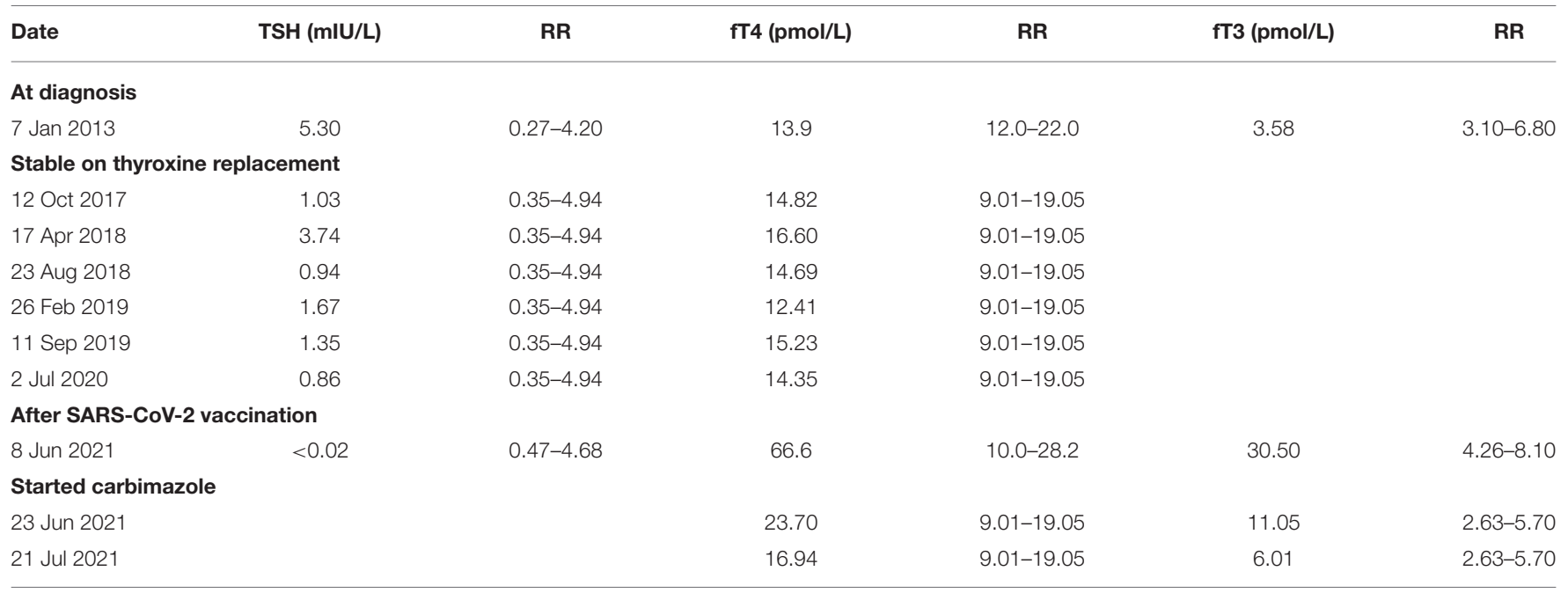

TSH, thyroid-stimulating hormone; $f T 4$, free thyroxine; $f T 3$, free triiodothyronine; $R R$, reference range. 


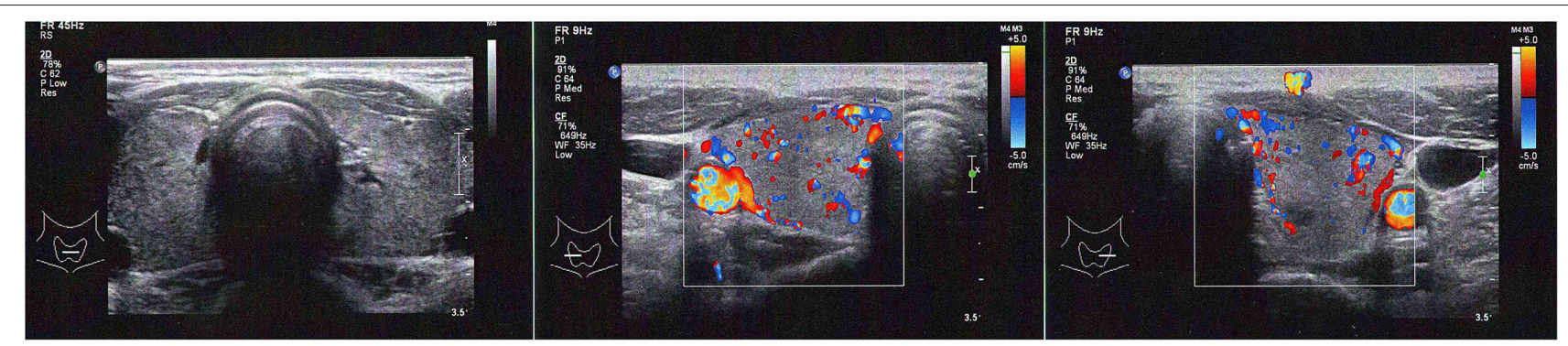

FIGURE 1 | Technetium thyroid scan at the diagnosis of Graves' disease of our patient.

markedly increased uptake over both lobes of thyroid, with associated increased blood flow and increased blood pool on dynamic images (Figure 2). Thyroxine replacement was stopped. She was put on carbimazole and propranolol, with subsequent improvement in the thyroid function (Table 1).

\section{Literature Review}

All the cases reported in the literature regarding thyroid dysfunction after SARS-CoV-2 vaccination are summarized in Table 2. There were 4 cases of Graves' disease after SARSCoV-2 vaccination, all occurring after mRNA vaccines (age ranged from 28 to 71 years, 3 women and 1 man). In addition, there were 9 cases of subacute thyroiditis reported after SARS-CoV-2 vaccination, which included mRNA, inactivated and adenovirus-vectored vaccines (age ranged from 26 to 67 years, 8 women and 1 man). These cases have been reported in countries in different continents including Asia, Europe, South America and North America.

\section{DISCUSSION}

Existing case reports of Graves' disease after SARS-CoV-2 vaccination manifested as the first episode in three patients $(8,9)$, and as relapse in one patient $(9)$. To our knowledge, our case report represents the fifth case of Graves' disease after SARS-CoV-2 mRNA vaccine in the literature. In contrast to the previous case presentations, the manifestation in our case was a less common presentation-Graves' disease on longstanding background of hypothyroidism requiring thyroxine replacement. The switch from hypothyroid to hyperthyroid state is believed to be stimulated by an external trigger, such as infection, in genetically susceptible individuals (10). Moreover, the development of de novo Graves' disease after COVID-19 is believed to take around 6-8 weeks (11). The combination of an uncommon presentation of Graves' disease with a compatible interval after the SARS-CoV-2 vaccination makes the causal relationship even more likely.

Graves' disease has been reported to temporally related to COVID-19, raising the possibility of SARS-CoV-2 in inducing autoimmune thyroid disorders (1). This postulation is supported by the fact that expression of angiotensin-converting enzyme
2 (ACE2), the functional receptor for SARS-CoV-2, is present in many endocrine organs including the thyroid (12). It is of clinical relevance whether SARS-CoV-2 vaccination may be associated with new onset autoimmune thyroid disorders by the same token, and more importantly, as SARS-CoV2 mRNA vaccines are the first mRNA vaccines in clinical use among human. Molecular mimicry has been proposed to cause thyroid dysfunction after SARS-CoV-2 vaccination. It has been shown that SARS-CoV-2 spike protein, nucleoprotein, and membrane protein all cross-reacted with thyroid peroxidase, and many thyroid peroxidase peptide sequences shared homology or similarity with sequences in various SARS-CoV-2 proteins (13). It is possible that SARS-CoV-2 proteins in the SARS-CoV-2 vaccines cross-react with thyroid target proteins due to molecular mimicry to cause autoimmune thyroid disorders such as Graves' disease. Interestingly, Graves' disease has only been reported among recipients of mRNA vaccines so far, in contrast to the reports of SARS-CoV-2 vaccine-related thyroiditis. The reasons are not entirely clear. As mRNA vaccines, encoding the SARS$\mathrm{CoV}-2$ spike protein, intrinsically could engage innate immunity that instructs induction of immune protection, the higher reactogenicity of the mRNA vaccine may cause a dysregulated immune system leading to emergence of autoimmune disorders $(14,15)$. Nonetheless, there could be underreporting of Graves' disease after other types of SARS-CoV-2 vaccines which leads to bias toward the association with mRNA vaccines. Whether family history of autoimmune or thyroid disorders, or genetic factors, may be predisposing factors, is unknown, as family history was not reported in most of these case reports of thyroid dysfunction post-SARS-CoV-2 vaccination, summarized in Table 2.

To date, all the five cases of Graves' disease after SARSCoV-2 vaccination are not associated with Graves' orbitopathy or thyroid dermopathy. Graves' orbitopathy has been reported to occur in $25 \%$ of patients with Graves' disease while thyroid dermopathy in $1.5 \%$ of patients with Graves' disease (16). There are factors, such as genetic predisposition or environmental factors, other than anti-TSH receptor antibody levels which contribute to the development of Graves' orbitopathy and thyroid dermopathy $(17,18)$.

The risk of occurrence of Graves' disease after vaccination has seldom been evaluated. The Vaccine Safety Datalink 


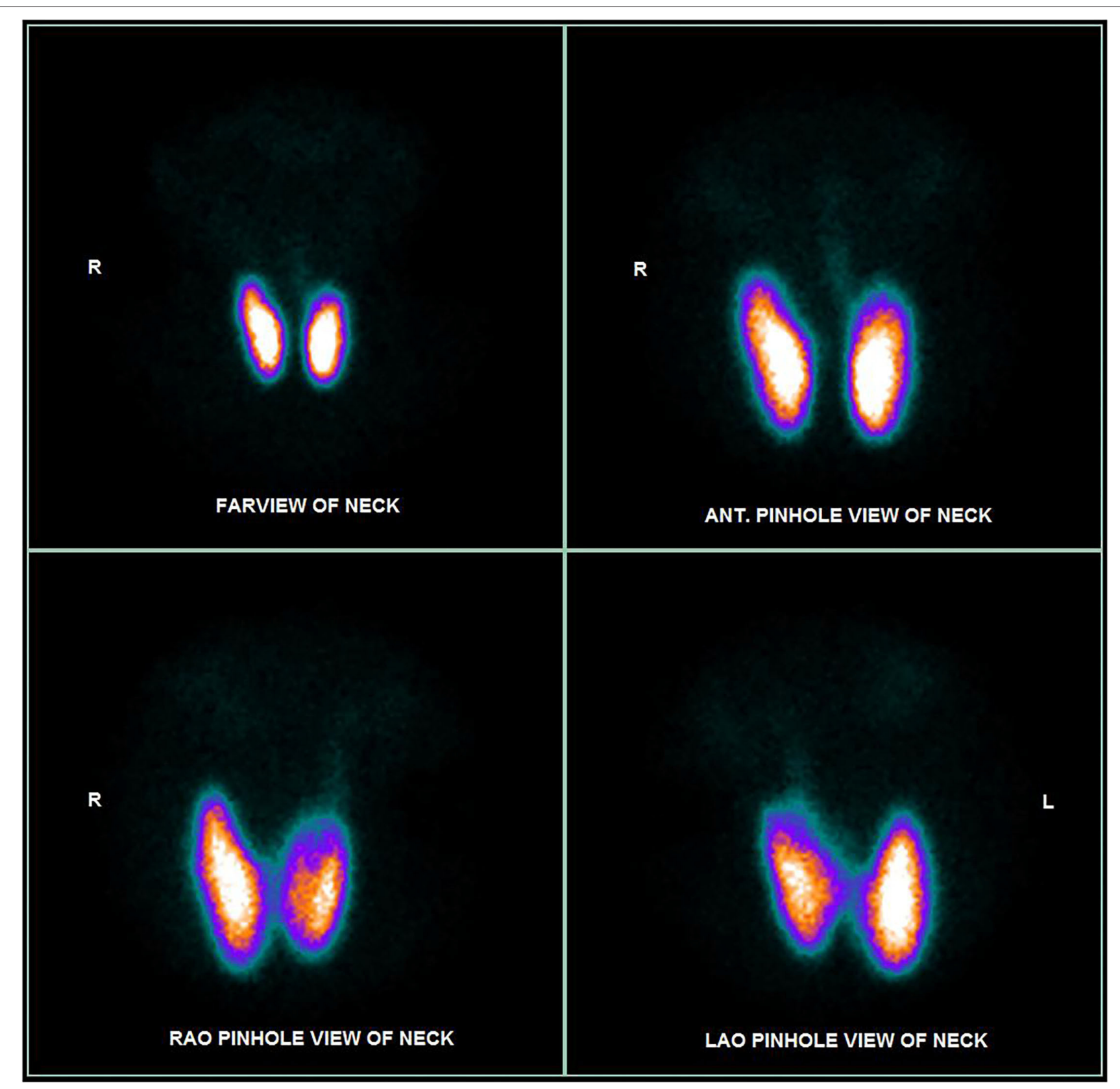

FIGURE 2 | Thyroid ultrasonography at the diagnosis of Graves' disease of our patient (left panel: both lobes without Doppler; mid panel: right lobe with Doppler; right panel: left lobe with Doppler).

study evaluated the risk of Graves' disease in recipients of hepatitis B vaccines, a kind of subunit vaccines (19). It did not show an increase in risk of Graves' disease in the ever-recipients, nor was there an association between the time interval between receipt of vaccines and Graves' disease.

In addition to the cases of Graves' disease, nine cases of subacute thyroiditis have been reported in the literature. We have summarized their features in Table 2. Of note, most of the patients presenting with thyroiditis had negative anti-thyroid antibody titers. Interestingly, the types of vaccines involved in these cases of thyroiditis include mRNA, inactivated and adenovirus-vectored SARS-CoV-2 vaccines.

Several mechanisms have been postulated for the occurrence of thyroiditis after SARS-CoV-2 vaccination. The most popular postulation is related to the vaccine adjuvants, contributing to the entity "autoimmune/inflammatory syndrome induced by adjuvants" (ASIA) (20). Post-vaccination phenomena are one of the manifestations in ASIA. Adjuvants are intentionally used to enhance the immunogenicity of vaccines to induce 
TABLE 2 | Case reports of thyroid dysfunction after SARS-CoV-2 vaccination.

\begin{tabular}{|c|c|c|c|c|c|c|c|c|c|}
\hline Sex/Age & Country & $\begin{array}{l}\text { Type of } \\
\text { vaccine }\end{array}$ & $\begin{array}{l}\text { Past health and } \\
\text { family history }\end{array}$ & $\begin{array}{l}\text { Time of onset } \\
\text { after vaccination }\end{array}$ & TFT at diagnosis & Thyroid Ab & $\begin{array}{l}\text { Thyroid } \\
\text { ultrasonography }\end{array}$ & $\begin{array}{l}\text { Technetium thyroid } \\
\text { scan }\end{array}$ & References \\
\hline \multicolumn{10}{|c|}{ Graves' disease } \\
\hline $\mathrm{F} / 40$ & Mexico & mRNA & $\begin{array}{l}\text { PH: hypertension, } \\
\text { COVID-19 } \\
\text { FH: N/A }\end{array}$ & 2 days later & $\begin{array}{l}\text { TSH }<0.001 \mathrm{mlU} / \mathrm{L} \text { (N: 0.27-4.4) } \\
\text { fT4 } 3.57 \mathrm{ng} / \mathrm{dL}(\mathrm{N}: 0.93-1.71) \\
\text { fT3 } 10.5 \mathrm{pg} / \mathrm{mL}(\mathrm{N}: 2.04-4.4)\end{array}$ & $\begin{array}{l}\text { Anti-TPO +ve } \\
\text { Anti-Tg + ve } \\
\text { TRAB + ve } \\
\text { TSI + ve }\end{array}$ & $\begin{array}{l}\text { Enlargement and } \\
\text { hypervascularity }\end{array}$ & $\mathrm{N} / \mathrm{A}$ & (8) \\
\hline$F / 28$ & Mexico & mRNA & $\begin{array}{l}\text { PH: good } \\
\text { FH: N/A }\end{array}$ & 3 days later & $\begin{array}{l}\text { TSH }<0.001 \mathrm{mIU} / \mathrm{L}(\mathrm{N}: 0.27-4.4) \\
\text { fT4 } 1.84 \mathrm{ng} / \mathrm{dL}(\mathrm{N}: 0.93-1.71) \\
\text { fT3 } 9.2 \mathrm{pg} / \mathrm{mL}(\mathrm{N}: 2.04-4.4)\end{array}$ & $\begin{array}{l}\text { Anti-TPO +ve } \\
\text { Anti-Tg -ve } \\
\text { TRAB + ve }\end{array}$ & N/A & Diffuse toxic goiter & (8) \\
\hline$F / 71$ & Austria & mRNA & $\begin{array}{l}\text { PH: Graves' } \\
\text { disease } \\
\text { FH: N/A }\end{array}$ & $\begin{array}{l}56 \mathrm{~d} \text { after } 1 \text { st dose } \\
35 \mathrm{~d} \text { after } \\
2 \text { nd dose }\end{array}$ & $\begin{array}{l}\text { fT4 } 3.56 \mathrm{ng} / \mathrm{dL} \text { (N: 0.70-1.70) } \\
\text { fT3 } 11.10 \mathrm{pg} / \mathrm{mL}(\mathrm{N}: 2.15-4.12)\end{array}$ & TRAB +ve & $\begin{array}{l}\text { Multiple confluent } \\
\text { anechogenic areas } \\
\text { and increased } \\
\text { vascularization }\end{array}$ & $\begin{array}{l}\text { Small (partly resected) } \\
\text { left lobe and the } \\
\text { enlarged right lobe with } \\
\text { a patchy } \\
\text { inhomogeneous tracer } \\
\text { distribution; mildly } \\
\text { increased uptake }\end{array}$ & (9) \\
\hline $\mathrm{M} / 46$ & Austria & mRNA & $\begin{array}{l}\text { PH: good } \\
\text { FH: N/A }\end{array}$ & $15 \mathrm{~d}$ after 1 st dose & $\begin{array}{l}\text { fT4 } 1.63 \mathrm{ng} / \mathrm{dL} \text { (N: 0.70-1.70) } \\
\text { fT3 } 5.18 \mathrm{pg} / \mathrm{mL} \text { (N: 2.15-4.12) }\end{array}$ & TRAB +ve & $\begin{array}{l}\text { Slightly enlarged } \\
\text { thyroid; In the } \\
\text { hypoechogenic } \\
\text { parenchyma, large } \\
\text { anechogenic areas } \\
\text { with increased } \\
\text { vascularization }\end{array}$ & $\begin{array}{l}\text { Patchy, very } \\
\text { inhomogeneous Tc99m } \\
\text { accumulation; normal } \\
\text { uptake }\end{array}$ & (9) \\
\hline \multicolumn{10}{|c|}{ Subacute thyroiditis } \\
\hline$F / 57$ & United States & mRNA & $\begin{array}{l}\text { PH: good } \\
\text { FH: N/A }\end{array}$ & $\begin{array}{l}35 \mathrm{~d} \text { after } 1 \text { st dose } \\
13 \mathrm{~d} \text { after } \\
2 \text { nd dose }\end{array}$ & $\begin{array}{l}\text { TSH }<0.008 \mathrm{mIU} / \mathrm{L}(\mathrm{N}: 0.4-4.2) \\
\text { fT4 } 1.92 \mathrm{ng} / \mathrm{dL} \text { (N: 0.8-1.5) TT3 } \\
137 \mathrm{ng} / \mathrm{dL} \text { (N: 87-178) }\end{array}$ & $\begin{array}{l}\text { Anti-TPO -ve } \\
\text { Anti-Tg -ve } \\
\text { TSI -ve }\end{array}$ & $\begin{array}{l}\text { Asymmetrically } \\
\text { enlarged } \\
\text { hypervascular } \\
\text { heterogeneous } \\
\text { right thyroid lobe }\end{array}$ & N/A & (2) \\
\hline$F / 49$ & Germany & mRNA & $\begin{array}{l}\text { PH: good } \\
\text { FH: father had } \\
\text { benign } \\
\text { thyroid nodules }\end{array}$ & $14 \mathrm{~d}$ after 1 st dose & $\begin{array}{l}\text { TSH } 0.5 \text { mIU/L (N: 0.35-4.94) } \\
\text { fT4 } 9.4 \text { ng/L (N: 7.0-14.8) } \\
\text { fT3 } 3.25 \text { ng/L (N: 1.71-3.71) }\end{array}$ & $\begin{array}{l}\text { Anti-TPO -ve } \\
\text { Anti-Tg -ve } \\
\text { TRAB -ve }\end{array}$ & $\begin{array}{l}\text { Distinct ill-defined } \\
\text { hypoechoic area } \\
\text { with decreased } \\
\text { blood flow }\end{array}$ & N/A & (3) \\
\hline$F / 35$ & Turkey & Inactivated & $\begin{array}{l}\text { PH: good } \\
\text { FH: nil }\end{array}$ & $\begin{array}{l}32 \mathrm{~d} \text { after } 1 \text { st dose } \\
4 \mathrm{~d} \text { after } 2 \text { nd dose }\end{array}$ & $\begin{array}{l}\text { TSH } 0.473 \mathrm{mlU} / \mathrm{L} \text { (N: 0.38-5.33) } \\
\text { fT4 } 14.1 \mathrm{pmol} / \mathrm{L} \text { (N: 7.86-14.41) } \\
\text { fT3 } 6.15 \mathrm{pmol} / \mathrm{L} \text { (N: 3.8-6.0) }\end{array}$ & $\begin{array}{l}\text { Anti-TPO -ve } \\
\text { Anti-Tg -ve } \\
\text { TRAB -ve }\end{array}$ & $\begin{array}{l}\text { Bilateral focal } \\
\text { hypoechoic areas } \\
\text { with decreased } \\
\text { blood flow }\end{array}$ & N/A & (4) \\
\hline
\end{tabular}


TABLE 2 | Continued

\begin{tabular}{|c|c|c|c|c|c|c|c|c|c|}
\hline Sex/Age & Country & $\begin{array}{l}\text { Type of } \\
\text { vaccine }\end{array}$ & $\begin{array}{l}\text { Past health and } \\
\text { family history }\end{array}$ & $\begin{array}{l}\text { Time of onset } \\
\text { after vaccination }\end{array}$ & TFT at diagnosis & Thyroid Ab & $\begin{array}{l}\text { Thyroid } \\
\text { ultrasonography }\end{array}$ & $\begin{array}{l}\text { Technetium thyroid } \\
\text { scan }\end{array}$ & Reference \\
\hline F/34 & Turkey & Inactivated & $\begin{array}{l}\text { PH: mild } \\
\text { COVID-19 } \\
\text { FH: nil }\end{array}$ & $4 \mathrm{~d}$ after 1 st dose & $\begin{array}{l}\text { TSH } 0.01 \mathrm{mlU} / \mathrm{L} \text { (N: 0.38-5.33) } \\
\text { fT4 } 11.8 \mathrm{pmol} / \mathrm{L}(\mathrm{N}: 7.86-14.41) \\
\text { fT3 } 5.2 \mathrm{pmol} / \mathrm{L} \text { (N: 3.8-6.0) }\end{array}$ & $\begin{array}{l}\text { Anti-TPO -ve } \\
\text { Anti-Tg -ve } \\
\text { TRAB -ve }\end{array}$ & $\begin{array}{l}\text { Bilateral focal } \\
\text { hypoechoic areas } \\
\text { with decreased } \\
\text { blood flow }\end{array}$ & N/A & (4) \\
\hline F/37 & Turkey & Inactivated & $\begin{array}{l}\text { PH: good } \\
\text { FH: nil }\end{array}$ & $7 \mathrm{~d}$ after 2 nd dose & $\begin{array}{l}\text { TSH } 0.9 \mathrm{mIU} / \mathrm{L} \text { (N: 0.38-5.33) } \\
\text { fT4 } 13.85 \mathrm{pmol} / \mathrm{L}(\mathrm{N}: \\
7.86-14.41) \\
\text { fT3 } 6.05 \mathrm{pmol} / \mathrm{L} \text { (N: 3.8-6.0) }\end{array}$ & $\begin{array}{l}\text { Anti-TPO -ve } \\
\text { Anti-Tg -ve } \\
\text { TRAB -ve }\end{array}$ & $\begin{array}{l}\text { Bilateral } \\
\text { hypoechoic areas } \\
\text { with irregular } \\
\text { borders and } \\
\text { reduced blood } \\
\text { flow }\end{array}$ & $\mathrm{N} / \mathrm{A}$ & (4) \\
\hline M/67 & Turkey & Inactivated & $\begin{array}{l}\text { PH: controlled } \\
\text { hypertension } \\
\text { FH: N/A }\end{array}$ & $\begin{array}{l}48 \mathrm{~d} \text { after } 1 \text { st dose } \\
20 \mathrm{~d} \text { after } \\
2 \text { nd dose }\end{array}$ & $\begin{array}{l}\text { TSH } 0.005 \mathrm{mlU} / \mathrm{L} \text { (N: 0.27-4.2) } \\
\text { fT4 } 2.87 \mathrm{ng} / \mathrm{dL} \text { (N: } 0.93-1.7) \\
\text { fT3 } 8.06 \mathrm{pg} / \mathrm{mL} \text { (N: } 2.7-4.3)\end{array}$ & $\begin{array}{l}\text { Anti-TPO -ve } \\
\text { Anti-Tg -ve } \\
\text { TRAB -ve }\end{array}$ & $\begin{array}{l}\text { Reduced } \\
\text { echogenicity and } \\
\text { diffusely } \\
\text { heterogeneous } \\
\text { texture with } \\
\text { pseudonodular } \\
\text { areas }\end{array}$ & $\mathrm{N} / \mathrm{A}$ & (5) \\
\hline F/32 & Brazil & Inactivated & $\begin{array}{l}\text { PH: good } \\
\text { FH: N/A }\end{array}$ & $\begin{array}{l}12 \mathrm{~h} \text { after } 2 \mathrm{nd} \\
\text { dose }\end{array}$ & $\begin{array}{l}\text { TSH } 13.2 \mathrm{mlU} / \mathrm{L} \text { (N: 0.45-4.5) } \\
\text { T4 normal }\end{array}$ & $\begin{array}{l}\text { Anti-TPO +ve } \\
\text { Anti-Tg +ve }\end{array}$ & $\mathrm{N} / \mathrm{A}$ & $\mathrm{N} / \mathrm{A}$ & (6) \\
\hline$F / 26$ & Germany & Inactivated & $\begin{array}{l}\text { PH: good } \\
\text { FH: nil }\end{array}$ & $14 \mathrm{~d}$ after 1 st dose & $\begin{array}{l}\text { TSH } 1.75 \mathrm{mlU} / \mathrm{L} \text { (N: 0.35-4.94) } \\
\text { fT4 9.3 ng/L (N: 7.0-14.8) } \\
\text { fT3 } 3.72 \mathrm{ng} / \mathrm{L}(\mathrm{N}: 1.71-3.71)\end{array}$ & $\begin{array}{l}\text { Anti-TPO -ve } \\
\text { Anti-Tg -ve } \\
\text { TRAB -ve }\end{array}$ & $\begin{array}{l}\text { Distinct ill-defined } \\
\text { hypoechoic areas } \\
\text { with decreased } \\
\text { blood flow }\end{array}$ & N/A & (3) \\
\hline F/55 & United Kingdom & $\begin{array}{l}\text { Adenovirus- } \\
\text { vectored }\end{array}$ & $\begin{array}{l}\text { PH: controlled } \\
\text { asthma } \\
\text { FH: nil }\end{array}$ & $21 \mathrm{~d}$ after 1 st dose & $\begin{array}{l}\text { TSH } 0.09 \mathrm{mlU} / \mathrm{L}(\mathrm{N}: 0.3-4.2) \\
\text { fT4 } 25.2 \mathrm{pmol} / \mathrm{L}(\mathrm{N}: 12.0-22.0)\end{array}$ & Anti-TPO -ve & $\begin{array}{l}\text { Enlarged thyroid } \\
\text { gland with } \\
\text { heterogeneous } \\
\text { echotexture } \\
\text { throughout; no } \\
\text { nodules or } \\
\text { hypervascularity }\end{array}$ & $\mathrm{N} / \mathrm{A}$ & (7) \\
\hline
\end{tabular}

F, female; $M$, male; d, days: PH, past health; FH, family history: TSH, thyroid-stimulating hormone; fT4, free thyroxine; fT3, free triiodothyronine; anti-TPO, anti-thyroid peroxidase; anti-Tg, anti-thyroglobulin; TRAB, TSH receptor antibody;

TSI, thyroid stimulating immunoglobulin; N/A, not available; Ab, antibody; TFT, thyroid function test. 
adaptive immune responses. Aluminum salts are commonly used for inactivated vaccines, and is the adjuvant for CoronaVac, the inactivated SARS-CoV-2 vaccine (20). A recent review of post-vaccination ASIA has summarized 50 cases of subacute thyroiditis after vaccination (influenza, human papillomavirus and hepatitis $B$ virus). Indeed, most are anti-thyroid antibody negative except in one case (21). The descriptions are consistent with the existing reports of SARS-CoV-2 vaccine-related subacute thyroiditis. BNT162b2 mRNA vaccine comprises a lipid nanoparticle formulated with a nucleoside RNA encoding a modified SARS-CoV-2 spike protein. The vaccine contains four lipids, of which two are polyethylene glycol (PEG) lipid conjugates that stabilize the lipid nanoparticles and reduce the activity of non-specific binding proteins (22). PEGs may act as an adjuvant and induce an immune response in predisposed individuals, as there are rare reports of reactions to PEGs (23). These probably explain the reports of subacute thyroiditis with SARS-CoV-2 vaccines using different platforms. A similar mechanism has also been postulated to explain the occurrence of Graves' disease postSARS-CoV-2 vaccination, as it has been shown that human papillomavirus-16/18 AS04-adjuvanted vaccine was associated with an incidence ratio of 3.75 for autoimmune thyroiditis among female (24).

Despite the extensive vaccination against SARS-CoV-2 globally, only a handful of cases of clinically overt thyroid dysfunction have been reported in the literature so far. This could either be related to underreporting or compatible with the rare incidence of post-vaccination adverse events in general. A systematic study of SARS-CoV-2 vaccine recipients regarding their changes in thyroid function and autoantibodies may shed light onto the extent of this problem. Our case report serves to remind clinicians of the potential presentation of thyroid dysfunction after SARS-CoV-2 vaccination.

\section{REFERENCES}

1. Mateu-Salat M, Urgell E, Chico A. SARS-COV-2 as a trigger for autoimmune disease: report of two cases of Graves' disease after COVID-19. J Endocrinol Invest. (2020) 43:1527-8. doi: 10.1007/s40618-020-01366-7

2. Schimmel J, Alba EL, Chen A, Russell M, Srinath R. Letter to the Editor: thyroiditis and thyrotoxicosis after the SARS-CoV-2 mRNA vaccine. Thyroid. (2021) 31:1440. doi: 10.1089/thy.2021.0184

3. Bornemann C, Woyk K, Bouter C. Case report: two cases of subacute thyroiditis following SARS-CoV-2 vaccination. Front Med. (2021) 8:737142. doi: $10.3389 /$ fmed.2021.737142

4. Iremli BG, Sendur SN, Ünlütürk U. Three cases of subacute thyroiditis following SARS-CoV-2 vaccine: postvaccination ASIA syndrome. J Clin Endocrinol Metab. (2021) 106:2600-5. doi: 10.1210/clinem/dgab373

5. Şahin Tekin M, Şaylısoy S, Yorulmaz G. Subacute thyroiditis following COVID-19 vaccination in a 67-year-old male patient: a case report. Hum Vaccin Immunother. (2021) 1-3. doi: 10.1080/21645515.2021.1947102

6. Leber HM, Sant'Ana L, Konichi da Silva NR, et al. Acute Thyroiditis and bilateral optic neuritis following SARS-CoV-2 vaccination with coronavac: a case report. Ocul Immunol Inflamm. (2021) 1-7. doi: 10.1080/09273948.2021.1961815

7. Oyibo SO. Subacute thyroiditis after receiving the adenovirus-vectored vaccine for coronavirus disease (COVID-19). Cureus. (2021) 13:e16045. doi: $10.7759 /$ cureus. 16045

\section{CONCLUSION}

Graves' disease can occur after SARS-CoV-2 vaccination. Our case represents the fifth in the literature of Graves' disease after SARS-CoV-2 vaccination, with an unusual presentation on a longstanding history of hypothyroidism. All the five cases reported thus far occurred after mRNA vaccine. Clinicians should remain vigilant about the potential manifestation of Graves' disease after SARS-CoV-2 vaccination in the current COVID19 pandemic.

\section{DATA AVAILABILITY STATEMENT}

The original contributions presented in the study are included in the article/supplementary material, further inquiries can be directed to the corresponding author/s.

\section{ETHICS STATEMENT}

Ethical review and approval was not required for the study on human participants in accordance with the local legislation and institutional requirements. The patients/participants provided their written informed consent to participate in this study.

\section{AUTHOR CONTRIBUTIONS}

DL and KT performed the literature search and drafted the manuscript. All authors coordinated the patient's care, read, and approved the final manuscript.

\section{ACKNOWLEDGMENTS}

We would like to thank our patient who provided the consent to participate in this study.

8. Vera-Lastra O, Ordinola Navarro A, Cruz Domiguez MP, Medina G, Sánchez Valadez TI, Jara LJ. Two cases of graves' disease following SARS-CoV-2 vaccination: an autoimmune/inflammatory syndrome induced by adjuvants. Thyroid. (2021) 31:1436-9. doi: 10.1089/thy.2021. 0142

9. Zettinig G, Krebs M. Two further cases of Graves' disease following SARS-Cov-2 vaccination. J Endocrinol Invest. (2021) 1-2. doi: 10.1007/s40618-021-01650-0

10. Ahmad E, Hafeez K, Arshad MF, Isuga J, Vrettos A. Hypothyroidism conversion to hyperthyroidism: it's never too late. Endocrinol Diabetes Metab Case Rep. (2018) 2018:18-0047. doi: 10.1530/EDM-1 8-0047

11. Inaba H, Aizawa T. Coronavirus disease 2019 and the thyroid - progress and perspectives. Front Endocrinol. (2021) 12:708333. doi: $10.3389 /$ fendo.2021.708333

12. Pal R, Banerjee M. COVID-19 and the endocrine system: exploring the unexplored. J Endocrinol Invest. (2020) 43:1027-31. doi: 10.1007/s40618-020-01276-8

13. Vojdani A, Vojdani E, Kharrazian D. Reaction of human monoclonal antibodies to SARS-CoV-2 proteins with tissue antigens: implications for autoimmune diseases. Front Immunol. (2021) 11:617089. doi: 10.3389/fimmu.2020.617089

14. Liang Z, Zhu H, Wang X, Jing B, Li Z, Xia X, et al. Adjuvants for coronavirus vaccines. Front Immunol. (2020) 11:589833. doi: 10.3389/fimmu.2020.589833 
15. Talotta R. Do COVID-19 RNA-based vaccines put at risk of immune-mediated diseases? In reply to "potential antigenic cross-reactivity between SARS-CoV2 and human tissue with a possible link to an increase in autoimmune diseases". Clin Immunol. (2021) 224:108665. doi: 10.1016/j.clim.2021.108665

16. Bartalena L, Fatourechi V. Extrathyroidal manifestations of Graves' disease: a 2014 update. J Endocrinol Invest. (2014) 37:691-700. doi: 10.1007/s40618-014-0097-2

17. Taylor PN, Zhang L, Lee RWJ, Muller I, Ezra DG, Dayan CM, et al. New insights into the pathogenesis and nonsurgical management of Graves orbitopathy. Nat Rev Endocrinol. (2020) 16:104-16. doi: 10.1038/s41574-019-0305-4

18. Fatourechi V. Thyroid dermopathy and acropachy. Best Pract Res Clin Endocrinol Metab. (2012) 26:553-65. doi: 10.1016/j.beem.2011.10.001

19. Yu O, Bohlke K, Hanson CA, Gatto NM, Caffrey AR. Hepatitis B vaccine and risk of autoimmune thyroid disease: a Vaccine Safety Datalink study. Pharmacoepidemiol Drug Saf. (2007) 16:736-45. doi: 10.1002/pds.1354

20. Watad A, David P, Brown S, Shoenfeld Y. Autoimmune/inflammatory syndrome induced by adjuvants and thyroid autoimmunity. Front Endocrinol. (2017) 7:150. doi: 10.3389/fendo.2016.00150

21. Bragazzi NL, Hejly A, Watad A, Adawi M, Amital H, Shoenfeld Y. ASIA syndrome and endocrine autoimmune disorders. Best Pract Res Clin Endocrinol Metab. (2020) 34:101412. doi: 10.1016/j.beem.2020.101412

22. $m R N A$ vaccines against COVID-19: Pfizer-BioNTech COVID-19 vaccine BNT162b2. Prepared by Strategic Advisory Group of Experts (SAGE) on Immunization Working Group on COVID-19 Vaccines. Geneva: World Health Organization (2020). Available online at: https://apps.who.int/iris/handle/ 10665/338096 (accessed Aug 28, 2021).
23. Garvey LH, Nasser S. Anaphylaxis to the first COVID-19 vaccine: is polyethylene glycol (PEG) the culprit? Br J Anaesth. (2021) 126:e106-8. doi: 10.1016/j.bja.2020.12.020

24. Willame C, Rosillon D, Zima J, Angelo MG, Stuurman A, Vroling $\mathrm{H}$, et al. Risk of new onset autoimmune disease in 9- to 25-year-old women exposed to human papillomavirus-16/18 AS04-adjuvanted vaccine in the United Kingdom. Hum Vaccin Immunother. (2016) 12:2862-71. doi: 10.1080/21645515.2016.1199308

Conflict of Interest: The authors declare that the research was conducted in the absence of any commercial or financial relationships that could be construed as a potential conflict of interest.

Publisher's Note: All claims expressed in this article are solely those of the authors and do not necessarily represent those of their affiliated organizations, or those of the publisher, the editors and the reviewers. Any product that may be evaluated in this article, or claim that may be made by its manufacturer, is not guaranteed or endorsed by the publisher.

Copyright (C) 2021 Lui, Lee, Lee, Lee, Hung and Tan. This is an open-access article distributed under the terms of the Creative Commons Attribution License (CC BY). The use, distribution or reproduction in other forums is permitted, provided the original author(s) and the copyright owner(s) are credited and that the original publication in this journal is cited, in accordance with accepted academic practice. No use, distribution or reproduction is permitted which does not comply with these terms. 